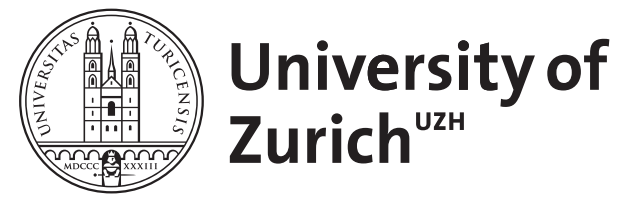

\title{
Entrepreneurial Signaling via Education: A Success Factor for Innovative
} Start-Ups

\author{
Backes-Gellner, Uschi ; Werner, A
}

DOI: https://doi.org/10.1007/s11187-006-0016-9

Posted at the Zurich Open Repository and Archive, University of Zurich ZORA URL: https://doi.org/10.5167/uzh-11903

Journal Article

Published Version

Originally published at:

Backes-Gellner, Uschi; Werner, A (2007). Entrepreneurial Signaling via Education: A Success Factor for Innovative Start-Ups. Small Business Economics, 29(1-2):173-190.

DOI: https://doi.org/10.1007/s11187-006-0016-9 


\section{Entrepreneurial Signaling via Education:} A Success Factor in Innovative Start-Ups

\begin{abstract}
Unlike traditional start-ups, innovative startups and their respective market partners are faced with severe problems of asymmetric information due to their lack of prior production history and reputation. Here, we study whether and how entrepreneurial signaling via education can help innovative entrepreneurs signal their abilities to banks and prospective employees. We argue that innovative entrepreneurs signal their quality by means of certain characteristics of their educational history. In particular, we expect potential employees to use an entrepreneur's university degree as a quality signal when deciding whether to accept a job at an innovative start-up, and we expect banks to use a more precise indicator, namely the actual length of study in relation to a standard length, as a signal when deciding to extend credit to an innovative founder. By contrast, traditional start-ups are not faced with the same problems of asymmetric information, so we do not expect employees or banks to require the same signals from them. We empirically test our hypotheses using a dataset of more than 700 German start-ups collected in 1998/99. All hypotheses are borne out by the data.
\end{abstract}

JEL CLASSIFICATION: M13, M5, D82, M21

\section{Introduction}

Start-ups in general and innovative start-ups in particular are often seen as an important factor in economic growth and job creation (Birch, 1979; Acs and Audretsch, 1990; Storey and Tether, 1996; Brüderl et al., 1998). However, compared to traditional start-ups, innovative start-ups are faced with unique problems and challenges

Final version accepted on March 92006

Uschi Backes-Gellner

Professor of Business and Personnel Economics

University of Zurich

Zurich, Switzerland

E-mail: backes-gellner@isu.unizh.ch

Arndt Werner

Institute for Small and Medium Size Enterprises

Bonn, Germany

E-mail: Werner@ifm-bonn.org
(Audretsch, 2000). Because of the innovative character of their product or business process, no prior history of comparable cases exists. Outside financiers of an innovative start-up, for example, have no relevant data about production facilities, processes, or product markets to use as benchmarks in evaluating a proposed business plan. The value of an innovative project is therefore difficult to judge, even for the most experienced of creditors. Accordingly, the asymmetric information gap between the founder of an innovative start-up and the creditor is likely to be extraordinarily large, potentially causing problems like credit rationing. ${ }^{1}$ Creditors may ration credit, finance only a fraction of assets and operations, claim high collateral, or shorten the length of their loans. Furthermore, other stakeholders may find investments in an innovative start-up particularly risky, given the lack of history, reliable benchmarks, and prior reputation. Employees may be reluctant to accept a job at such a company, i.e. to invest in company-specific knowledge if the risk of failure is too high or totally unknown. Suppliers may be hesitant to grant trade credit, and customers may be cautious about ordering products of possibly unacceptable quality or products that may not be delivered in due course. Taken together, these problems reduce the probability of a start-up becoming successful and growing unimpeded. In other words, founders of innovative start-ups who find a way to overcome the initial problem of asymmetric information in the relevant markets are likely to run their new venture more successfully (see e.g. Hunsdiek/May-Strobl, 1986; Binks/ Ennew, 1996; Egeln et al., 1997; Falk, 1999)

The objective of our paper is to determine whether educational signals of innovative founders can help to solve or reduce their labor market and credit market problems. ${ }^{2}$ Reversing Spence (1973), who argues that workers signal 
unobservable productivity to an employer by acquiring an educational degree, we argue that, likewise, entrepreneurs, whom we assume to be fully aware of their own productivity, signal unobservable entrepreneurial productivity by observable characteristics of their educational biography to potential employees, or lenders, customers etc. Since the market partners of innovative entrepreneurs cannot readily observe the quality of their venture, they have an incentive to approximate that information via reliable signals. According to our theoretical considerations we expect potential employees to use an innovative entrepreneur's university degree as a quality signal when deciding whether to accept a job at an innovative start-up. In addition, we expect banks to use a more precise indicator, namely the actual length of study in relation to a standard length, as a signal when deciding upon start-up credit for an innovative founder. Although in general there may also be other ways for highly productive entrepreneurs to signal the above average quality of their venture, such as collateral or bonds, we do not consider them to be a complete substitute for educational signals but rather complementary instruments, because in the special situation of innovative founders they are not available, or not to a sufficient degree. Accordingly, for innovative entrepreneurs, we expect educational signals to be particularly important and therefore investigate their impact on labor market and credit market access.

Since the situation is different for traditional start-ups, where potential creditors or employees can draw upon prior start-up cases and business history to evaluate the risk of a start-up, we do not expect the same signals to be used to classify the quality of innovative and of traditional start-ups. To test our hypotheses we use German firm level data collected in 1998/99, containing 790 start-ups which were founded between 1992 and 1997 in the Cologne area. All predictions are borne out by the data, leading us to conclude that educational signals are effective instruments for reducing the problems of asymmetric information on the credit and labor market for innovative but not for traditional founders.

The paper is organized as follows. In the next section, we summarize the literature on entrepreneurial signaling. In the third section, we explain what kind of educational signal may act as a valid signal for innovative entrepreneurs and derive five empirically testable hypotheses. In the fourth section on "Data, Measurement Issues, and Methodology" we describe our data set, which is derived from a large sample of start-ups in the greater Cologne area, Germany, and discuss measurement and methodological issues. In the fourth section, we present our econometric results; and finally, we summarize and draw some tentative conclusions.

\section{Entrepreneurial signaling in capital and labor markets - theoretical analysis}

Start-ups in general, and innovative start-ups in particular, have no prior financial or internal labor market history, and hence, no reputation. For innovative product or business processes, there is no experience and no benchmark on which to build. Given this situation, it is most likely that a founder will be better informed about the potential gains, losses, and risks of the innovative venture than outside stakeholders like financiers, whom the founder needs for credit, or employees, who are needed at the latest when companies start to grow $(58 \%$ of the start-ups in our sample started with at least one employee; $42 \%$ without any employees).

\subsection{Literature}

The situation of asymmetric information can cause severe problems such as adverse selection and even credit rationing. Many papers focus on the efficiency of debt-financed ventures in general, and on credit rationing or underinvestment in start-ups in particular. One strand of these papers assumes the existence of credit rationing and concentrates either on the causes of credit rationing ${ }^{3}$ and underinvestment, on the effects of credit rationing on efficiency, or on the effects of corrective government actions on credit rationing (see Parker, 2004, sec. 5 for a survey of the literature). A second strand of papers argues that it is possible to eliminate credit rationing by using various instruments to reveal hidden information. These instruments range from reputation through relationship banking, signaling and/or screening to using 
collateral and bonds. Examples of screening by banks offering a menu of contract options include collateral (cf. Bester, 1985), joint liability under group lending (cf. Ghatak and Guinnane, 1999); offering limited and unlimited liability debt contracts to entrepreneurs (cf. Chamley, 1983) and offering a high initial interest rate in a multi-period setting (cf. Webb, 1991; Boot and Thakor, 1994). Parker (2004) offers a summary of the screening arguments favoring the idea that rationing can be eliminated by banks writing more sophisticated financial contracts to reveal the hidden information.

We argue that most of these instruments that reveal hidden information are unsuitable for innovative start-ups: since the business idea and the company are both totally new, there is no reputation or experience to build on. ${ }^{4}$ Sufficient collateral is often beyond the means of a typical founder and therefore banks often cannot even use extended collateral as a screening mechanism (Parker, 2004).

However, we argue that educational signaling, as introduced by Spence (1973) for employees, is a plausible way of dealing with the information asymmetries of innovative entrepreneurs, as it implies using a person's past behavior in other activities, namely schooling, to draw conclusions about their future productivity in a new venture. Moreover, such an instrument is applicable even for the most innovative founders.

The role of educational signals for entrepreneurs has rarely been analyzed in depth, despite some early mentions in the economics literature. In the late 1970s there was a first discussion on how the educational degrees of employees vs. entrepreneurs could be used to test the educational screening hypothesis (cf. Wolpin, 1977; Lazear, 1977; or more recently, Lofstrom, 2000). Wolpin argues that entrepreneurs should have lower levels of education if schooling is merely a signal, because there is no need for entrepreneurs, who are by definition selfemployed, to signal. Lazear, on the other hand, argues that educational signals might not be irrelevant for entrepreneurs because customers may use their credentials as a signal in assessing product quality. However, this argument was never systematically followed up in entrepreneurship research. While educational signaling is sometimes briefly mentioned in the entrepreneurship literature (see for example Nooteboom, 1993) it has rarely been studied in-depth, either theoretically or empirically.

In this paper we attempt to close this gap by showing in our theoretical section why and what type of signals are relevant in which entrepreneurial market, and by presenting empirical evidence to support our hypotheses. The study that comes closest to our analysis is that of Parker and van Praag (2005), who study how the performance of a start-up is affected by capital constraints and human capital. Since they for the first time treat human capital and financial capital as an endogenous variable, their paper includes a question similar to ours as part of their model.

They concentrate on type I credit rationing and extend the model of Bernhardt (2000) to deal with the impact of human capital on firm performance. Unlike Bernhardt (2000), they allow for heterogenous entrepreneurs (differing in exogenous ability) and study the consequences under two different assumptions, i.e. unobserved or observed ability of the entrepreneur (the latter case being similar to that assumed in our paper). Whereas, according to their model, in the case of unobserved ability, lenders use a common screening technology to assess ability and therefore rate all lenders with the same error, in the case of observed ability, lenders assess and classify ability by certified human capital (i.e. years of schooling), which is assumed to perfectly reflect ability. Parker and van Praag (2005) show that under the assumption that physical capital and human capital are not complements, greater human capital decreases borrowing constraints. However, if human and physical capital are complements, the effect is ambiguous if no additional assumptions are made. With the additional assumption that better educated entrepreneurs are less over-optimistic and therefore demand capital more carefully than poorly educated entrepreneurs, greater human capital still reduces borrowing constraints. What we call entrepreneurial signaling, is similar to what Parker and van Praag (2005) analyze in their case of observed heterogenous ability. We also assume heterogeneity among innovative start-ups facing the bank as a lender and the 
worker as a potential employee with the problem of adverse selection. Since in the case of innovative start-ups other instruments like reputation, business history or collateral are nonexistent, creditors and potential employees can only use the educational history of the founder as a screening device. Based on the propositions of Parker and van Praags model with heterogenous ability and asymmetric information, we also expect innovative entrepreneurs to be faced with fewer credit constraints (and fewer labor shortages) if they possess a better educational signal. However, since we assume that in the case of traditional start-ups, banks as well as potential employees have numerous other and more reliable indicators with which to screen heterogenous entrepreneurs, such as their business and employment history or collateral and bonds, we do not expect that educational signals have a similar effect on credit constraints or labor shortages for traditional start-ups. But even for innovative founders, not all educational characteristics can serve alike as reliable productivity indicators. As shown by Spence (1973) there are several conditions that have to be met in order for an educational signal to be able to guarantee a separating equilibrium, i.e. an equilibrium which reliably separates entrepreneurs with high probability of success from entrepreneurs with low probability of success.

\subsection{Preconditions for educational signals}

According to Spence (1973) educational degrees have to meet two additional criteria to become valid as a signal separating high quality from low quality employees. In the original model, where employees signal their unobserved productivity, the degree firstly must be closely related to the type of productive capability employers are looking for in filling a particular job vacancy. For example, if a company is looking for a creative and trendy hairdresser it might not be best to hire a Ph.D. just because he has the highest educational degree among the applicants. Secondly, in order to guarantee a separating equilibrium, the cost to the employee of obtaining the degree must be strongly negatively correlated with the employee's hidden productivity. Only in this case will low-quality employees not invest in the degree, because their costs are higher than their future returns. Only if both conditions are met will employers willingly pay a premium for the signal (the educational degree) because only then does it guarantee a separating self-selection equilibrium. Reversing Spence's original model, we have to determine what type of educational history for an innovative founder is likely to meet these two conditions. Thus, in what follows we first study the type of ability that is required of innovative founders and makes them more likely to be successful on innovative markets. In the second step we analyze what type of educational history is likely to separate high ability from low ability innovative founders due to the different cost attached to them.

\subsection{Ability requirements of innovative founders and requirements in the educational system}

As shown in a number of empirical studies, innovative markets are characterized by rapid technological change, short product life cycles, and rather volatile market conditions (see e.g. McDermott and O'Connor, 2002). Founders who want to survive in such an environment must be able to work continuously and rapidly through a large amount of new market information, quickly and efficiently filtering out what is important and flexibly deriving new solutions. Given this environment, a founder needs analytical and problem-solving skills, selfdirection, and endurance (Lück and Böhmer, 1994). On the other hand, in dynamic environments like those of innovative start-ups, narrow occupational skills are very quickly worthless. And the more innovative a product, a business process, or a market is, the shorter is the half-life of specific occupational skills. However, the ability to reason, analyze, communicate, and crosscheck information is of enduring value, even for the most innovative founders. This assumption was confirmed when entrepreneurs were asked about the usefulness of a variety of their skills in a survey of more than 700 entrepreneurs $^{5}$ (cf. Table I). Innovative founders find general analytical and problem-solving skills more helpful than traditional founders. 
Conversely, traditional founders consider more specialized occupational skills, such as product knowledge, marketing skills and finance tools to be more helpful (see Table I). Within the German educational system it is assumed that the first type of skill is typical of a university education, whereas the latter type is typical, e.g., of a traditional vocational education. Our assumption is confirmed by a comparison of the educational backgrounds of innovative and non-innovative entrepreneurs: $47 \%$ of innovative founders hold a university degree, whereas only $39.7 \%$ of traditional founders do so. It therefore seems reasonable to assume that a university degree is likely to provide the typical

TABLE I

Usefulness of different kinds of skills and knowledge for start-ups ${ }^{\mathrm{a}}$

\begin{tabular}{|c|c|}
\hline $\begin{array}{l}\text { Were the following skills and } \\
\text { subjects you acquired during } \\
\text { your university education } \\
\text { helpful for your start-up? } \\
(1=\text { not at all helpful; } \\
5=\text { very helpful) }\end{array}$ & $\begin{array}{l}\text { Mean } \\
\text { value }\end{array}$ \\
\hline \multicolumn{2}{|l|}{$\begin{array}{l}\text { Analytical and general } \\
\text { problem solving skills }\end{array}$} \\
\hline Innovative start-ups & 4.21 \\
\hline Traditional start-ups & 4.10 \\
\hline \multicolumn{2}{|l|}{ Product-specific knowledge } \\
\hline Innovative start-ups & 3.73 \\
\hline Traditional start-ups & 3.87 \\
\hline \multicolumn{2}{|l|}{ Knowledge on taxation } \\
\hline Innovative start-ups & 3.28 \\
\hline Traditional start-ups & 3.63 \\
\hline \multicolumn{2}{|l|}{ Marketing-specific knowledge } \\
\hline Innovative start-ups & 2.97 \\
\hline Traditional start-ups & 3.50 \\
\hline \multicolumn{2}{|l|}{ Labor law and labor } \\
\hline Innovative start-ups & 2.77 \\
\hline Traditional start-ups & 3.17 \\
\hline \multicolumn{2}{|l|}{ Finance-tools } \\
\hline Innovative start-ups & 2.89 \\
\hline Traditional start-ups & 3.21 \\
\hline
\end{tabular}

a Judgements of 790 founders included in the Cologne Founder Study (CFS). skills that are a precondition to becoming a successful innovative entrepreneur.

\subsection{Educational signals and separating equilibrium}

If it is assumed that general analytical and problem-solving skills are the most important skill requirements for a successful innovative founder, the next question is what kind of educational history guarantees a separating equilibrium for these types of skills. The first part of our answer concerns the type of education associated with the analytical and general skills mentioned above. Within the German educational system it is common knowledge that these general analytical and problem-solving skills are the ones required for university studies. They are considered to be indispensable for obtaining a university degree. Thus, founders holding a university degree can be assumed to be better prepared to run an innovative start-up than founders without a university degree. In addition, we argue that students with a higher level of problem-solving and analytical skills are not only able to complete their studies but also to study faster and receive their university degree in a shorter period of time than students with a lower level of problem-solving skills. Since in Germany students have high flexibility regarding the length of their studies, it seems natural to use the timespan it takes a student to finish a university degree as a precise signal of their underlying capability. Thus, length of study, which is not to be confused with years of schooling in the Anglo-Saxon tradition of measuring the stock of human capital, ${ }^{6}$ should be given priority as a signal if this information is available.

A number of studies support our assumption that length of study is a reliable indicator for classifying the productivity of university degree holders. Berning (1982) investigates whether certain work and study techniques used by law students determine the time they take to complete their studies. He finds that students who take longer to graduate show lower concentration, are less able to work without interruption, suffer more often from self-motivation problems, and are less able to identify obstacles and find solutions to overcome them. Differences in 
length of study, then, are the result of systematic productivity differences. Furthermore, Schaeper and Minks (1997) show not only a correlation between better grades and shorter length of study but also that extracurricular activities do not slow down good students. Thus, it is reasonable to assume that within the German university system a shorter length of study (all else being equal) can act as a potential signal for higher ability students ${ }^{7}$ and thus for more productive innovative entrepreneurs.

In the second step we have to ask whether length of study is likely to guarantee a separating equilibrium, i.e. whether it reliably separates high quality types from low quality types of innovative founders. In order to guarantee a separating equilibrium, the costs of attaining a signal have to be sufficiently negatively correlated with ability, i.e. the cost of signaling high quality has to be substantially higher for a person with a low level of analytical and problem solving skills, less endurance, and less ability for self-directed work than for a person with high level of skills (including the signal not being manipulable by the students themselves). There are two types of empirical evidence that we can draw on to provide evidence for a strong negative correlation in the German university system. First, the failure rate at German universities is quite high, making it very expensive for low ability students to complete studies for a university degree. In 2002, the average failure rate was about 25 percent across all fields and universities (IWD, 2002), so the cost for low ability students literally extends to infinity. In addition, there is high variance in length of study, which shows a strong negative correlation with the quality of the students as measured by their grades (although one could naively assume that taking more time to study might lead to better grades due to longer study times). We can clearly illustrate our assumption by looking at some numbers within the German university system. In the fields of management and economics, for example, the standard length of study for a Master's degree in Germany, according to official study guidelines, is $4 \frac{1}{2}$ years, but the average length of study is much longer at about $5 \frac{1}{2}$ to 6 years. Only 14.5 percent of the students are able to finish their studies within the standard time (Wissenschaftsrat, 2002); all others take much longer due to exams or failed courses they have to repeat. Unfortunately, there is no Germanywide data on the relation between length of study and grading, but we were able to obtain full record data from the largest university in Germany, the University of Cologne, which is ranked among the highest in its fields. In stark contradiction to the naïve view, the data clearly confirm our assumption of a strong negative relation between length of study and ability (cf. Table II). In 2001, the average length of study for a Master's in management and economics at the University of Cologne was approximately $6 \frac{1}{2}$ years (13 semesters). Only 3 percent of the students were able to finish in fewer than 9 semesters, while 10 percent needed more than 16 semesters. The faster students (with lower than average length of study) are the better students (with better grades) while slower students have worse grades, which clearly indicates that length of study can be used as a reliable, non-manipulable quality indicator.

TABLE II

Length of study and average grades in diplomas in management and economics at the University of Cologne $\left(\right.$ fall 2001) ${ }^{\mathrm{a}}$

\begin{tabular}{lccl}
\hline $\begin{array}{l}\text { Length } \\
\text { of study }\end{array}$ & $N$ & Percentage & $\begin{array}{l}\text { Average } \\
\text { grade }^{\mathrm{b}}\end{array}$ \\
\hline $\begin{array}{l}\text { Less than } \\
\text { 4.5 years }\end{array}$ & 9 & 3.3 & 2.00 \\
$\begin{array}{l}4.5 \text { years } \\
\text { 5 years }\end{array}$ & 12 & & \\
5.5 years & 25 & 4.0 & 2.40 \\
6 years & 84 & 18.6 & 2.53 \\
6.5 years & 18 & 8.0 & 2.59 \\
7 years & 37 & 27.6 & 2.75 \\
7.5 years & 7 & 6.0 & 2.90 \\
8 years & 22 & 12.3 & 2.93 \\
More than & 30 & 2.3 & 2.90 \\
8 years & & 7.3 & 2.99 \\
Average: & Total: & 10.0 & 3.14 \\
6.9 years & 300 Students & & Average \\
\hline
\end{tabular}

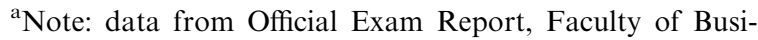
ness, Economics and Social Sciences, University of Cologne (Cologne, 06.05.2002).

blower grade numbers indicate better diplomas (best grade $=1.0$; worst grade $=5.0$ ). 
Thus, given the empirical evidence for Germany, it is reasonable to assume that educational signals establish a separating equilibrium, because holding a university degree guarantees a minimum level of the type of skills required to run an innovative start-up (students with too few skills fail before they finish a university degree). Secondly, a shorter length of study guarantees a higher level of those same skills than a longer length of study because length of study is negatively correlated with quality of students.

\subsection{Availability of information}

However, since a person's educational history can only serve as a signal if it is available to a market partner looking for a screening device to overcome asymmetric information, it is first necessary to determine what type of information is available to whom. Here the situation is different for banks as lenders and for workers as potential employees. Empirical studies show that commercial banks always use a number of screening devices to evaluate a start-up, among which a detailed business plan is indispensable (Egger and Gronemeier, 1999). ${ }^{8}$ Therefore, if banks consider a university degree and length of study valuable information, they can easily obtain it and use it for their credit decision. Since we argue that length of study is a more telling signal than just holding a degree, we expect banks to make use of it. Thus, innovative founders who took less time to obtain a given degree should have fewer problems acquiring the credit they want than slower students.

Unlike banks, workers as potential employees usually have only limited information about the educational history of their future employer. In most cases, employees can easily discover whether a founder holds a university degree. ${ }^{9}$ However, it is unlikely that an employee will find out about the length of study. Therefore, we expect that employees can and will use the existence of a university degree as a signal for the unobservable quality of the innovative founder, but not the length of university study. ${ }^{10}$ Thus, innovative founders with a university degree will have less difficulty recruiting qualified employees than innovative founders without one.

\subsection{Patents as an alternative signal for banks}

Patents are very similar to educational signals as a screening device. Holding or not holding a patent can also serve as a credible signal for the unobservable quality of an innovative founder because only the most creative and productive founders will be able to file a patent. ${ }^{11}$ Since patents are again only readily observable by banks (by means of the business plan), but not by employees, we expect patents to function as a signal for banks but not for potential employees.

To summarize, we expect the data to confirm the following five patterns (Hypotheses 1-5):

A. Labor market shortages

1. Innovative founders with a university degree have less difficulty recruiting qualified employees than innovative founders without a university degree.

2. For traditional founders, holding a university degree does not make a difference (or only very little) in recruitment problems because, unlike innovative founders, they are not subject to the same problem of asymmetric information.

\section{B. Credit market constraints}

3. Innovative founders with a shorter length of study have fewer problems obtaining the credit they ask for than innovative founders with longer length of study for the same degree.

4. For traditional founders a shorter length of study does not make a difference to credit problems.

5. Innovative founders holding a patent have less difficulty obtaining credit than innovative founders without patents.

\section{Data, measurement issues, and methodology}

To test the predictions about entrepreneurial signaling, we analyzed a dataset of 790 start-ups in the Cologne area. The data were collected in $1998 / 99$ in a project on regional determinants and effects of entrepreneurship and cover a representative sample of start-ups from 1992 to 1997. ${ }^{12}$ Almost two thirds of the start-ups are in the service sector (62 percent); a quarter are in retailing, and 13 percent are in manufacturing. 
Eighty-seven percent of the firms are true start-ups (23\% are takeovers); however, only 18 percent of the start-ups are innovative start-ups, while the rest are traditional start-ups. Average turnover in the first year was 728,000 Euros. The founders were predominantly male (79 percent), 36 years old on average, and often highly qualified (44 percent held a university degree and 7 percent a doctoral degree). For each start-up, we have a 6-page questionnaire with a broad spectrum of questions on the founder and his or her personal background (education, experience), the economic background of the start-up (sources and difficulties obtaining start-up capital), its current financial situation, human resources issues, production technology, networks, and social capital. (for more details on the Cologne Founder Study, see Backes-Gellner et al., 2000).

\subsection{Dependent variables}

As a first dependent variable we need a variable to measure a founder's difficulty in recruiting a sufficient number of employees. Unfortunately, we do not have explicit data on labor shortages. However, we do have a variable specifying what percentage of employees must be classified as overloaded with work in the year 1997. We assume that work overload among employees is highly correlated with job vacancies and thus with recruiting problems, because incumbent employees must take over the workload of vacant positions. Therefore we use the percentage of employees classified as overloaded with work as an indicator for recruitment problems. Since labor shortage can also be driven by excessive growth or turnover we have to control for short term business cycle effects and therefore include profit and turnover in the years prior to 1997 in our labor market regression. ${ }^{13}$

As a second dependent variable we need a variable measuring difficulty in obtaining a sufficient amount of credit at reasonable conditions (interest rates, collateral, maturity of loans). There are several ways how credit constraints can be measured. Previous research has tended to use indirect indicators of wealth, inheritance or windfall gains to test the effect of capital constraints on performance (Evans and
Jovanovic, 1989; Black et al., 1992, Holtz-Eakin et al., 1994, Lind and Ohlsson, 1996). A positive correlation between wealth and entrepreneurship performance is said to indicate capital constraints. The drawback of these approaches is that they do not reveal whether the entrepreneurs were able to obtain external capital. Parker and van Praag (2005) construct a measure of capital constraints in which the total amount of capital used at the start of the new business is related to the amount of capital required. Although we do not have hard facts on the amount or the conditions of our founders' credit, we do have a very good indirect indicator that should reflect all these aspects simultaneously. In our survey, founders were asked whether, during their start-up phase, it was difficult to obtain the credit they initially needed for their start-up. They answered using a 5-point Likert scale from $1=$ very problematic to $5=$ not at all problematic. It is important to note that our rating of the credit problems does not refer to the current situation in the company but to the situation at the beginning of the start up, which is exactly what the variable should cover for our purposes. The respondents were asked whether they had experienced difficulty in obtaining sufficient credit at the time they started their business. In using a subjective rating we assume that less favorable hard facts will be reliably reflected in a lower subjective evaluation score. Such an assumption is supported by Binks and Ennew (1996), who argue that a subjective classification is a useful proxy for credit constraints because individual difficulties in obtaining credit correspond to unfavorable credit conditions. Moreover, Van Praag (2003) uses a direct individual indicator for initial credit constraints which is very similar to ours ("Did you experience problems in obtaining sufficient (external) capital at the start of your venture?'). On the other hand, Parker (2004) points out that claims by survey respondents that they face(d) credit constraints should be treated with great caution because they are prone to self-serving bias whereby entrepreneurs might blame banks for inherent shortcomings. However, since our respondents were asked a few years after start-up time, we assume that this bias had dissipated by the time of our survey. 
A subjective indicator, furthermore, has the advantage of capturing various kinds of constraints in just one indicator. On the basis of a large German data set, Egeln et al. (1997) find a very strong correlation between a firm's selfclassification of credit problems and the official rating given by Creditreform, Germany's largest credit-rating agency. Thus, we are confident that a subjective rating of credit problems during the start-up phase reliably identifies the real credit problems of the start-up. Since our subjective rating refers to credit problems in obtaining the initial credit during the start-up phase, there is no need to control for performance variables as would be the case if we asked about credit problems in an already running company. Hence typical endogeneity problems connected with entering performance variables in a credit constraints regression are also avoided.

\subsection{Independent variables}

To test our five hypotheses we need three major explanatory variables. First, we distinguish three educational levels based on the educational history of the founder: 1 . founders who hold a doctoral degree as their highest university degree, 2. founders who hold a standard university degree, such as a Diploma, a Master's or Magister Artium, and 3. founders who never received a university degree, including both those who never started higher education and those who are dropouts. Our dummy variables are DD for holding a doctoral degree and UD for holding a university degree (the reference group consists of the founders with no university degree).

Our second independent variable, the length of study, is not as easy to measure as the degrees, given the German university system with all its heterogeneity. Respondents were asked how many years they had taken to finish their respective degree, which gives us numbers for actual length of study. However, we cannot simply compare these numbers across different types of universities. For example, finishing a degree in a typical research university in 6 years might be fast, whereas finishing a degree in a university of applied sciences in 6 years might be very slow when compared to what is standard for that type of university. Therefore, we have to render the raw numbers comparable by a standardization. In order to do so, we use the average number of years at a given university as a benchmark to make the individual lengths of study comparable. ${ }^{14}$ Thus we have students studying faster than average (FASTUD) and students studying more slowly than average (SLOWUD). The reference groups are founders without a university degree. Our third independent variable, patents, is a dummy variable. PATENT $=1$ if a founder holds a patent, and zero if he or she does not hold a patent.

Finally, we must separate innovative from non-innovative start-ups, because we only expect the university degree and length of study to be effective as a signal for innovative but not for traditional start-ups. This is daunting, given the difficulty of clearly defining "innovativeness" and due to additional data restrictions (Acs and Gifford, 1996). In general, a variety of indicators can be used to measure a firm's innovative activity. These are typically $R \& D$ expenditure, number of patents held, average R\&D-intensity in an industry, or various subjective measures of innovation (cf. Acs and Audretsch, 1990; Brüderl et al., 1996). In our dataset, we have information on patents, R\&D expenditures at firm and industry level, venture capital backing, and collaboration with external research facilities. Table III, which shows how these variables are correlated in our sample, is used to identify a reliable indicator to separate innovative from non-innovative start-ups.

Correlations among our five innovation measures indicate that they are all positively correlated. However, the level of significance shows that only the number of patents and R\&D intensity on industry level are closely related to all other indicators. On firm level, collaboration with external research facilities, venture capital backing, and R\&D expenditure perform slightly worse, in the sense that they correlate with a smaller number of indicators. Therefore, to encompass most of the information in one indicator and at the same time avoid too many missing cases we should use either the number of patents or R\&D intensity on industry level (a similar method is used by Brüderl et al., 1996). Since the number of patents is available only for a very small number of firms in our 
TABLE III

Correlation $^{\mathrm{b}}$ matrix of various innovation indicators ${ }^{\mathrm{a}}$

\begin{tabular}{lllll}
\hline Patents & $\begin{array}{l}\text { R\&D intensity } \\
\text { on firm level }\end{array}$ & $\begin{array}{l}\text { Venture } \\
\text { capital backing }\end{array}$ & $\begin{array}{l}\text { Collaboration with } \\
\text { research facilities }\end{array}$ & $\begin{array}{l}\text { R\&D-intensity } \\
\text { in industry }\end{array}$ \\
\hline $\begin{array}{l}\text { Patents } \\
\begin{array}{l}\text { R\&D investments } \\
\text { on firm level }\end{array}\end{array}$ & $0.097^{* *}$ & $0.069^{*}$ & $0.148^{* * *}$ & $0.094^{* * *}$ \\
$\begin{array}{l}\text { Venture capital } \\
\begin{array}{l}\text { Alliances with } \\
\text { research facilities }\end{array}\end{array}$ & -0.007 & $0.147^{* *}$ & $0.137^{* * *}$ \\
\hline
\end{tabular}

${ }^{a}$ Note: Data are from Cologne Founder Study (CFS)

$\mathrm{b} * * *$ Significant at the 1 percent level; ** Significant at the 5 percent level; * Significant at the 10 percent level.

dataset, we decided to use R\&D intensity on industry level to distinguish innovative from non-innovative founders because it is available for all start-ups in the sample. However, as is shown in Table III, R\&D intensity correlates significantly with all other innovation indicators (a similar classification is used by Almus and Nerlinger, 1999).

In addition to the variables derived from our five hypotheses, we use a number of standard control variables, which are specified in Table IV.

\subsection{Methodology}

Since our dependent variable "percentage of overloaded workers" is left censored at zero and right censored at 1 , we use a Tobit model to test our labor market implications. To test our credit market implications, we use an ordered probit model, because the dependent variable "credit problems" is ordinal, which makes OLS regressions inappropriate.

\section{Empirical results}

\subsection{Labor market signaling of innovative entrepreneurs}

Table $\mathrm{V}$ displays the results of Tobit estimations with the percentage of overloaded workers as the dependent variable and INNOVSU, DD, UD, SLOWUD and FASTUD as the main explanatory variables.

In a first model, we use a specification that includes only the vector of control variables that was described in Table IV and the dummy variable for innovative (INNOVSU) vs. non-innovative founders. In a second model, we use the two university education dummies (DD, UD) and patents as additional variables. And in a third model, we also include interactions between doctoral degree and innovative startup, university degree and innovative start-up, and patent and innovative start-up. With the interaction term, we allow the educational signals to differ for innovative and non-innovative start-ups because, in accordance with our theoretical considerations, we expect entrepreneurial signaling with education to be important for innovative founders only. All our hypotheses on entrepreneurial signaling on labor shortages are borne out by the data.

Firstly, in accordance with our hypotheses, we find that university degrees (UD, DD) and patents do not have a significant effect on labor shortages as long as innovative and noninnovative founders are not separated. An incremental $F$-test clearly indicates that the variables introduced in the second model, i.e. DD, UD and PATENT, do not add explantory power $(F(3,209)=1.12$; Prob $>F=0.3424)$. However, if we distinguish between innovative and non-innovative founders, educational degrees do matter. An incremental F-test shows that the goodness of fit increases significantly $(F(6,206)=2.30 ;$ Prob $>F=0.0357)$, which confirms the relevance of the interaction variables added in model 3. The interaction variable UD*INNOVSU captures the additional effect a university degree has for an innovative start-up. The coefficient is negative and highly significant, meaning that innovative founders with a university degree have significantly lower 


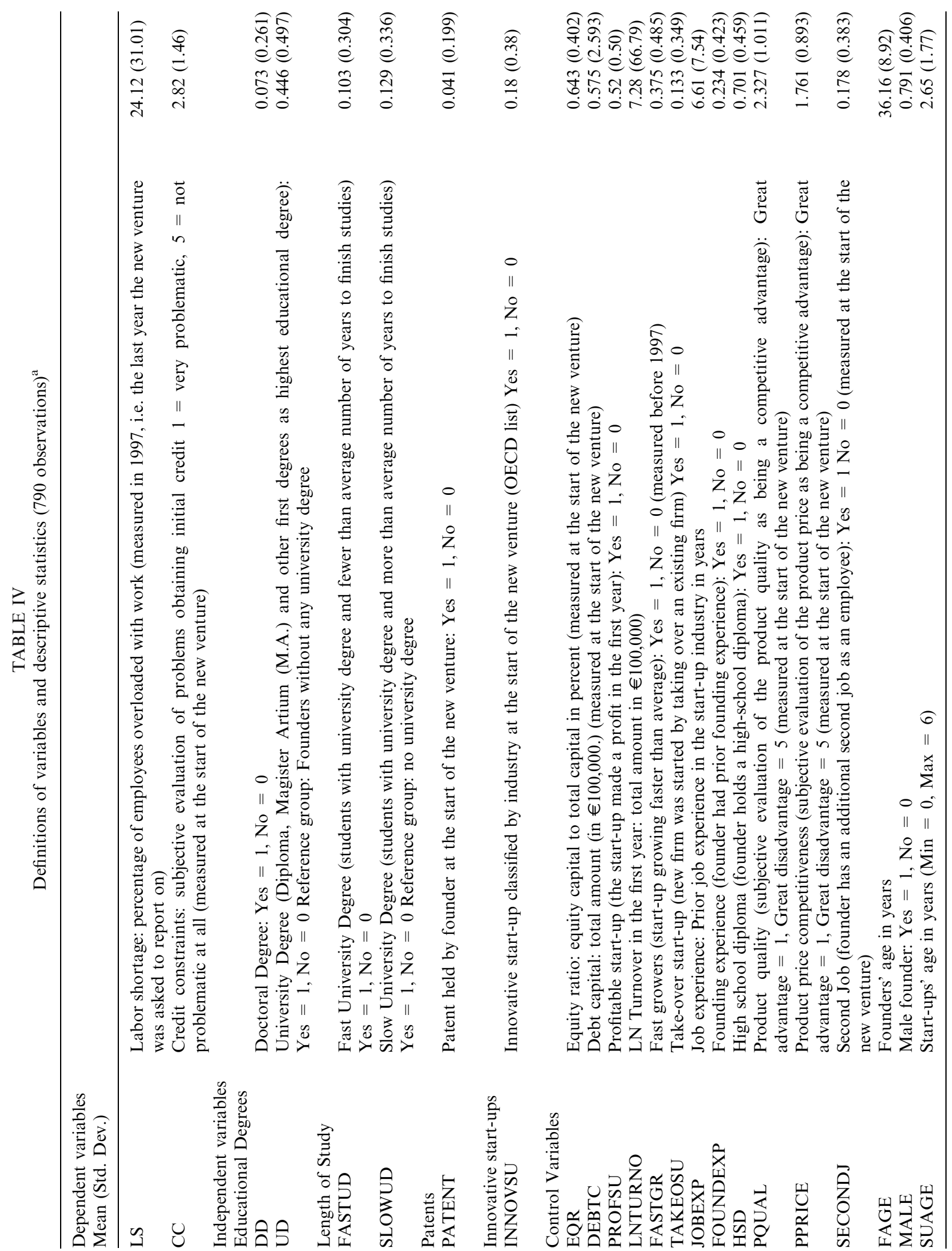


percentages of overloaded workers than innovative founders without a university degree. This is consistent with hypothesis 1 . At the same time, UD by itself is not significant, which is consistent with hypothesis 2 . On the labor market university degrees do not serve as a signal in general, but only in the special case of innovative start-ups. As anticipated in our theoretical considerations, patents do not have a significant effect on labor shortages. Somewhat surprisingly, doctoral degrees also have no significant effect (in any of the models). One reason could be the small number of cases in our sample. A second reason could be that most of the hidden information relevant for an innovative start-up is already captured by the first university degree and/or that between a doctoral and a standard university degree a pooling and not a separating equilibrium exists.

As for our control variables, we find that faster growing start-ups (FASTGR) and growth-targeted start-ups (with plans for future investments, GROSU) have significantly more problems recruiting the required number of qualified employees, which is consistent with previous empirical evidence on labor shortages of start-ups. Take-over start-ups (TAKEOSU) have significantly less difficulty with labor shortage problems, which we think is because they have already existed for a longer time and can be assumed to have a reputation, making the educational signaling of the founder no longer relevant. In addition, they are a less risky venture for a potential employee because their failure rate is significantly lower on average, which is also consistent with the negative sign we find. All other control variables are also unsurprising.

\subsection{Credit market signaling of innovative entrepreneurs}

To test our hypotheses on credit problems we use ordered probit estimations. The dependent variable should be interpreted as follows: the lower the subjective credit problem indicator, the more difficulty the founder experienced obtaining the required credit during the start-up phase (the situation is worse); the higher the indicator, the easier it was to obtain the required 
TABLE V

Tobit regression results: Entrepreneurial signaling and labor market constraints ${ }^{\mathrm{a}}$

\begin{tabular}{|c|c|c|c|}
\hline Independent variables ${ }^{\mathrm{c}, \mathrm{d}}$ & $\begin{array}{l}\text { Model } 1 \\
\text { Coeff. ( } t \text {-value) }\end{array}$ & $\begin{array}{l}\text { Model } 2 \\
\text { Coeff. ( } t \text {-value) }\end{array}$ & $\begin{array}{l}\text { Model } 3 \\
\text { Coeff. ( } t \text {-value) }\end{array}$ \\
\hline INNOVSU & $11.036(1.24)$ & $11.434(1.28)$ & $36.371(2.53)^{* *}$ \\
\hline $\mathrm{DD}^{\mathrm{b}}$ & & $21.617(1.51)$ & $20.582(1.37)$ \\
\hline $\mathrm{UD}^{\mathrm{b}}$ & & $2.637(0.28)$ & $15.430(1.50)$ \\
\hline PATENT & & $13.831(0.87)$ & $11.934(0.61)$ \\
\hline DD * INNOVSU & & & $34.621(0.98)$ \\
\hline UD $*$ INNOVSU & & & $-48.530(-2.69)^{* * *}$ \\
\hline PATENT * INNOVSU & & & $9.872(0.31)$ \\
\hline PROFSU & $-7.421(-1.05)$ & $-6.543(-0.93)$ & $-3.856(-0.56)$ \\
\hline LNTURNO & $4.057(2.07)^{* *}$ & $3.989(2.05)^{* *}$ & $3.221(1.69)^{*}$ \\
\hline FASTGR & $11.303(1.46)$ & $11.396\left(1.47^{*}\right.$ & $9.903(1.31)$ \\
\hline TAKEOSU & $-15.661(-1.60)$ & $-14.475(-1.48)$ & $-11.606(-1.21)$ \\
\hline HSD & $11.772(1.44)$ & $7.956(0.77)$ & $3.455(0.34)$ \\
\hline FAGE & $0.413(0.96)$ & $0.348(0.79)$ & $0.337(0.79)$ \\
\hline MALE & $11.795(0.84)$ & $11.658(1.18)$ & $10.620(1.11)$ \\
\hline SUAGE & $2.188(0.84)$ & $2.075(0.79)$ & $1.541(0.60)$ \\
\hline CONST & $-81.559(-2.57) * *$ & $-79.289(-2.49) * *$ & $-69.442(-2.23)^{* *}$ \\
\hline Number of observations & 223 & 223 & 223 \\
\hline LR-Chi ${ }^{2}$ & $23.67 * *$ & $27.00 * *$ & $37.83^{* * *}$ \\
\hline$R^{2}$-Pseudo & 0.0157 & 0.0179 & 0.0251 \\
\hline
\end{tabular}

${ }^{a}$ Note: Data are from Cologne Founder Study (CFS)

${ }^{\mathrm{b}}$ Reference group: no college/no university degree

${ }^{\mathrm{c}}$ All regressions include dummies indicating economic sectors (manufacturing, trade, services)

d*** Significant at the 1 percent level; ** Significant at the 5 percent level; $*$ Significant at the 10 percent level.

credit (the situation is better). Table VI displays the results for four different models.

In the first model, we again begin with a specification including the vector of control variables only and the distinction between innovative and non-innovative start-ups. We find that credit problems are significantly worse for innovative start-ups than that for noninnovative start-ups, which is in accordance with our assumption that the probability of information asymmetry is substantially higher for innovative start-ups.

In the second model we add our first set of explanatory variables, i.e., the university degree dummies (UD, DD) and the interaction terms with innovative start-ups (INNOVSU $\times$ DD, INNOVSU $\times$ UD). University degrees alone obviously do not serve as a signal for creditors, either in general or for innovative start-ups. In the third model, we add length of study and the respective interaction term to see whether banks use the more precise signal "length of study" for their credit decisions for innovative start-ups (hypothesis 3) but not for non-innovative startups (hypotheses 4). First of all we find that adding the length of studies and the respective interaction terms increases the goodness of fit substantially. Secondly we find that the only significant variable is the interaction term FASTUD * INNOVSU, which is significantly positive as expected in hypothesis 3 . Innovative founders who completed their studies faster than average are better at obtaining credit than those whose studies took longer than average. Thirdly, we find that FASTUD and SLOWUD have no significant effect on credit problems in general, which is consistent with hypothesis 4 .

In the fourth and last model, we add patents and the respective interaction term and find that patents significantly reduce the credit difficulties of innovative start-ups, which confirms hypothesis 5. If innovative founders hold a patent, it is significantly easier for them to obtain credit. Furthermore, being among the faster students makes it even easier to obtain credit. 
TABLE VI

Ordered probit regression results: Entrepreneurial signaling and credit market constraints ${ }^{\mathrm{a}}$

\begin{tabular}{|c|c|c|c|c|}
\hline Independent variable $e^{\mathrm{c}, \mathrm{d}}$ & $\begin{array}{l}\text { Model } 1 \\
\text { Coef. (z-value) }\end{array}$ & $\begin{array}{l}\text { Model } 2 \\
\text { Coef. (z-value) }\end{array}$ & $\begin{array}{l}\text { Model } 3 \\
\text { Coef. (z-value) }\end{array}$ & $\begin{array}{l}\text { Model } 4 \\
\text { Coef. ( } z \text {-value) }\end{array}$ \\
\hline INNOVSU & $-0.501(-2.12)^{* *}$ & $-0.680(-1.97)^{* *}$ & $-0.727(-2.07)^{* *}$ & $-0.710(-2.03)^{* *}$ \\
\hline $\mathrm{DD}^{\mathrm{b}}$ & & $0.257(0.71)$ & $0.351(0.96)$ & $0.311(0.85)$ \\
\hline $\mathrm{UD}^{\mathrm{b}}$ & & $0.134(0.49)$ & & \\
\hline FASTUD $^{b}$ & & & $0.234(0.70)$ & $0.199(0.59)$ \\
\hline SLOWUD $^{\mathrm{b}}$ & & & $0.197(0.61)$ & $0.130(0.40)$ \\
\hline PATENT & & & & $0.601(1.11)$ \\
\hline DD * INNOVSU & & $0.226(0.33)$ & $0.269(0.39)$ & $0.237(0.34)$ \\
\hline UD * INNOVSU & & $0.334(0.68)$ & & \\
\hline FASTUD * INNOVSU & & & $1.529(2.28) * *$ & $1.549(2.31)^{* *}$ \\
\hline SLOWUD * INNOVSU & & & $-0.372(-0.63)$ & $-0.941(-1.47)$ \\
\hline PATENT * INNOVSU & & & & $1.792(1.68)^{*}$ \\
\hline EQR & $1.549(1.24)$ & $1.651(1.31)$ & $2.059(1.61)$ & $2.134(1.66)^{*}$ \\
\hline EQR(SQR) & $-1.543(-1.41)$ & $-1.599(-1.45)$ & $-1.889(-1.69)^{*}$ & $-2.056(-1.82)^{*}$ \\
\hline DEBTC & $5.6 \mathrm{e}-08(0.37)$ & $4.5 \mathrm{e}-08(0.28)$ & $4.3 e-08(0.26)$ & $-2.7 \mathrm{e}-07(-1.30)$ \\
\hline JOBEXP & $0.019(1.32)$ & $0.023(1.51)$ & $0.026(1.71)^{*}$ & $0.031(1.99)^{* *}$ \\
\hline FOUNDEXP & $0.218(1.02)$ & $0.257(1.18)$ & $0.328(1.49)$ & $0.421(1.89)^{*}$ \\
\hline PQUAL & $-0.108(-1.04)$ & $-0.099(-0.95)$ & $-0.099(-0.94)$ & $-0.114(-1.08)$ \\
\hline PPRICE & $0.119(1.37)$ & $0.105(1.18)$ & $0.117(1.30)$ & $0.120(1.31)$ \\
\hline TAKEOSU & $-0.010(-0.03)$ & $-0.033(-0.10)$ & $0.074(0.23)$ & $0.261(0.80)$ \\
\hline HSD & $0.012(0.06)$ & $-0.118(-0.46)$ & $-0.227(-0.87)$ & $-0.085(-0.32)$ \\
\hline SECONDJ & $-0.089(-0.35)$ & $-0.105(-0.41)$ & $-0.186(-0.71)$ & $-0.263(-0.98)$ \\
\hline FAGE & $0.001(0.04)$ & $-0.004(-0.28)$ & $-0.003(-0.18)$ & $-0.010(-0.66)$ \\
\hline MALE & $-0.259(-0.94)$ & $-0.281(-1.02)$ & $-0.310(-1.12)$ & $-0.309(-1.11)$ \\
\hline MARRIED & $0.332(1.52)$ & 0.317 (1.37) & $0.317(1.37)$ & $0.331(1.43)$ \\
\hline CHILD & $-0.328(-1.35)$ & $-0.308(-1.24)$ & $-0.299(-1.20)$ & $-0.279(-1.12)$ \\
\hline Number of obs. & 170 & 170 & 170 & 170 \\
\hline LR-Chi ${ }^{2}$ & $33.11^{*}$ & $34.65^{*}$ & $43.45^{* *}$ & $50.40 * *$ \\
\hline$R^{2}$-Pseudo & 0.062 & 0.065 & 0.081 & 0.094 \\
\hline
\end{tabular}

${ }^{a}$ Note: Data are from Cologne Founder Study (CFS)

${ }^{\mathrm{b}}$ Reference: no college/no university degree

${ }^{\mathrm{c}}$ All regressions include dummies indicating economic sectors (manufacturing, trade, services) and founding year (1992-1997) $\mathrm{d} * * *$ Significant at the 1 percent level; ** Significant at the 5 percent level; * Significant at the 10 percent level.

To summarize, studying faster than average makes it easier for innovative founders to obtain credit, but not for non-innovative founders, which supports our assumption that for traditional start-ups, banks can build on their experience, use traditional benchmarks to evaluate a business plan and use traditional screening devices such as collateral, making it unnecessary to use educational signals to evaluate an unobservable quality. However, for innovative start-ups, banks cannot build on experience and prior information or reputation, so they use educational signals and patents when deciding upon credits. In reaching this decision, they do not take just any element of an applicant's educational history as a credible signal, but instead carefully select the most telling indicators that are available. They prefer more precise signals, i.e., length of study, rather than less precise signals, i.e., the university degree itself. And they obviously use multiple signals if available, i.e. they use patents and length of study at the same time. The results are consistent with our entrepreneurial signaling explanation.

As for our control variables, we find an inverted U-shaped relationship between equity rates (EQR) and credit problems. This finding is consistent with what we find in the literature on optimal financial structures of (new) firms (e.g. Harris and Raviv, 1991, Brüderl et al., 1996; Huyghebaert and van de Gucht, 2002). Job experience (JOBEXP) and previous founding 
experience (FOUNDEXP) both reduce credit problems significantly, which is in line with findings on success factors for start-ups showing that job experience and experience as a founder reduce the likelihood of failure. The rest of the control variables are unspectacular and contain no surprises.

\section{Conclusion}

Compared to traditional start-ups, innovative start-ups are faced with the problem that there is no prior history of similar production or business processes. Additionally, their ex ante default risk is higher, and, due to missing company history and prior ties, there is no reputation to make up for the missing information. As a result, innovative start-ups, and their market partners are faced with severe problems of asymmetric information. We focus on the role of educational signals in solving or substantially reducing these information problems and thereby increasing the potential success of innovative start-ups. We focus our analysis on credit and labor market problems because it has been shown that they are crucial to the success of innovative start-ups, i.e. shortage of credit in the early start-up phase and shortage of qualified employees in the initial growth period. In analogy to the standard labor market-signaling model developed by Spence (1973), we assume that not only employees but also entrepreneurs credibly signal their quality by means of certain characteristics of their educational history. However, as Spence shows, educational characteristics must meet certain conditions to become a valid and credible signal. Therefore, we first analyze what kinds of capabilities are particularly required to run an innovative startup and what kind of educational career requires these same capabilities (first condition). In a second step, we study what aspect of an educational career guarantees a sufficiently negative correlation between the cost of acquiring the signal and the quality of the innovative founder, so as to guarantee a separating equilibrium (second condition). Finally, we determine what kind of information is available to which market partner at what cost. Based on a detailed analysis of the concrete situation for employees and banks concerning these three conditions, we hypothesize that potential employees will use a university degree as an important quality signal when deciding whether to accept a job at an innovative start-up, and that banks will use a more accurate indicator, namely the length of study, as a credible signal when deciding upon credit for an innovative founder. To our knowledge, an entrepreneur's university degree and the actual length of study have not been used before in investigating the determinants of credit and labor market shortages in the case of innovative start-ups.

Banks will, additionally, use the existence of a founder's patents as a signal for the quality of his or her innovative start-up. Although we do not expect the same signals to be used for traditional start-ups, since the problem of asymmetric information is not as pronounced, and because there are a number of other (often more reliable) instruments available for screening the quality of traditional start ups.

We tested our hypotheses using a dataset of 790 start-ups collected in and around Cologne in 1998/99. Consistent with what we expected, we find that innovative - and only innovative founders holding a university degree have fewer problems of labor shortage, i.e. a lower percentage of overloaded workers, indicating that they have fewer problems attracting enough qualified employees. Also consistent with our hypotheses, we find that innovative - and only innovative - founders experience fewer problems obtaining the credit they initially need to start their venture if they finished their university degree faster than others, i.e. in less than the average number of years. Furthermore, if innovative founders hold a patent, this also makes it easier for them to obtain sufficient credit. As predicted by our theoretical considerations of asymmetric information, patents do not reduce credit problems for traditional start-ups, which confirms our assumption that patents merely act as a signal in banks' credit decisions, but less as an instrument guaranteeing property rights and market shares, because then they would also act in the same way for traditional start-ups.

To conclude, we show that entrepreneurial signaling via education is obviously a powerful 
instrument in overcoming typical problems of asymmetric information for innovative start-ups, an aspect which has rarely been analyzed. The dearth of studies is largely due to a lack of adequate data. We present a unique database covering not only a wide range of variables on the newly founded enterprises but also on the founders and their educational background, labor market experience, and personal history. Since one of our main results is that a university degree and length of study are important signals, particularly for innovative founders, we conclude that - contrary to what popular discussion during the internet boom period often suggested completing (!) an education with a degree is particularly important for innovative founders, even more than for traditional founders. During the boom years of the new economy, many students in Germany (and elsewhere) considered it a waste of time to complete their studies and work for a degree because innovative businesses did not seem to require or honor traditional educational values. Students dropped out en masse, many of them with the aim of becoming one of the new stars on the glamorous innovative start-up-horizon. However, our empirical results indicate that traditional educational patterns and values, such as finishing an education and meeting a time target, are even more important for innovative markets than for traditional markets, where other credible quality indicators might be available.

\section{Acknowledgements}

Financial support from the German Science Foundation under grant no. Ba $1832 / 1-1$ is appreciated. We are grateful to Edward P. Lazear, Alwine Mohnen and the participants of two German Science Foundation-workshops at Rauischholzhausen and Munich, and the 2003 annual conferences of the German Association of Management and the German Association of Economics. The views expressed herein and all errors are, however, the authors' alone.

\section{Notes}

1 Asymmetric information and adverse selection does not necessarily result in credit rationing. And credit constraints do not always imply inefficiency or market failure (Stiglitz and Weiss, 1983; Besanko and Thakor, 1987). De Meza and Webb (1987) for example propose a model with assumptions similar to those of the most influential credit-rationing model of Stiglitz and Weiss (1981), but with the opposite effects; i.e. over-investment and too much entrepreneurship instead of credit rationing. However, the majority of studies assume credit rationing and analyze either Type I rationing (rationing via loan size) or Type II rationing (rationing via selection of loan applicants) and their negative consequences such as a shortage of start-ups.

2 Note that the models specified and tested in our paper concentrate on access to capital and labor markets and the impact of educational signals. Thus, our study is in line with previous research of Bates (1990), Storey and Tether (1996), Binks and Ennew (1996), Blumberg and Letterie (2004) or Astrebo and Bernhardt (2005). This paper is not concerned with new venture performance (e.g. survival duration, business profits, etc.) and direct effects on financial or human capital (see for example, Evans and Jovanovic, 1989; Cooper et al., 1994; Holtz-Eakin et al., 1994; Moog and Backes-Gellner, 2003; Van Praag, 2003; Moog, 2004 or Bosma et al., 2004, Parker and van Praag, 2005).

3 However, tighter constraints might still not be inefficient. They might decrease profits of entrepreneurs, but this does not necessarily imply inefficiency or market failure (Parker and van Praag, 2005) because borrowing constraints can be an efficient market reaction. On the other hand, if one assumes positive externalities like innovation spillovers, which are often shown to be important in a regional context, credit restrictions might become a problem and could justify government intervention to relax them but only in special cases.

4 Lenders usually rely on 'carcass' evaluation and refrain from thoroughly screening every single innovative entrepreneur's credibility as this is unlikely to be cost effective. Ravid and Spiegel (1997) argue that start-ups in particular are too small and complex, economies of scale are non-existent and therefore thorough individual screening does not pay.

5 The descriptive data were generated as a by-product of the study described in section 3 of this paper. For more details on the dataset see section 3 .

6 "Years of schooling" as typically used in Anglo-Saxon studies is a proxy for the highest school level attained, whereas our variable "length of study" can be used to distinguish graduates provided they have obtained a university degree. The key difference is that more years of schooling or education signal higher quality whereas, here, higher length of study signals lowers quality.

7 The assumption is also supported by a major study by Bankhofer and Hilbert (1995), who investigated the recruitment process of companies. They found that 74 percent of the firms considered grades, and 69 percent considered length of study to be (very) important for hiring decisions. The assumption is also consistent with a number of empirical studies on labor market entrants' wages. Schaeper and Minks (1997) analyze the wages of 11,300 labor market entrants with university degrees and find that students who study faster than average earn an additional $200 \mathrm{DM} /$ month (approximately \$100). In addition, Minks 
(1992) shows that students taking longer than average have higher unemployment spells after finishing their studies and are more often forced to accept less favorable jobs (e.g. temporary work and freelance activities).

8 A successful business plan provides detailed information about the loan applicant via a CV showing educational institutions, fields and dates of study, and degrees earned.

9 In the simplest case, an employee can read the nameplate at the start-up office or check the telephone book or official registers. Also, with little effort, an employee can find out about an employer's educational background from a Chamber of Commerce.

10 It is important to note that for a signaling equilibrium to exist it is not necessary that an innovative founder is aware that he is acquiring a signal when attending university (as argued in the traditional signaling model for employees): all a potential founder has to know is that by obtaining more education he or she will increase future profits. Nor do employees have to know anything about signaling; all that is necessary is that employees faced with the decision to accept a job in an innovative start-up believe that holding a university degree makes an innovative founder more successful, with better prospects for future work.

11 Amit et al. (1990) argue that prototypes, which are similar to patents, are a valid quality signal for innovative founders because more productive founders will develop prototypes at lower costs than less productive founders.

12 The data were collected with financial support from the German National Science Foundation (DFG) under project number STE 628/5-1, the German Founder Bank (Deutsche Ausgleichsbank, DtA) and the Cologne Savings Bank. We thank Petra Moog and Güldem Demirer for introducing us to their dataset.

13 Because our performance variables (profit and turnover) are lagged variables, i.e. they cover the period prior to the period in which we measure the percentage of overloaded workers, it seems reasonable to assume that performance is not endogenous in our labor shortage regression. To see whether our results are stable, we also estimated the labor market models without performance variables. All estimated results are highly stable. Overall, (prior) performance does not seem to have a large impact on labor shortages in start-ups anyway. To control for wage effects we also estimated models including a variable 'labor cost share' (i.e. relation of labor cost to firm's total cost). Here again, the estimated results do not differ significantly from the results in the previous specification. Since we lose a large number of cases in this enlarged specification due to a substantial increase in missing variables, we decided to drop the variable 'labor cost share' in our final specification.

14 Because of data restrictions, we were only able to calculate reliable averages for the different university types of the founders who received their degree from one of the Cologne universities (81.3 percent of the sample), but not for those studying at universities other than Cologne. Therefore, we had to select only Cologne students for our regression. Among them we created two groups of students: Cologne fast and Cologne slow students.

\section{References}

Acs, Z. J. and D. B. Audretsch, 1990, Innovation and Small Firms, Cambridge: MIT Press.

Acs, Z. J. and S. Gifford, 1996, 'Innovation of Entrepreneurial Firms', Small Business Economics 8, 203-218.

Almus, M. and E. A. Nerlinger, 1999, 'Growth of new Technology-Based Firms: Which Factors Matter?', Small Business Economics 13, 141-154.

Amit, R., L. Glosten and E. Muller, 1990, 'Does Venture Capital Foster the most Promising Firms?', California Management Review 32, 102-111.

Astebro, T. and I. Bernhardt, 2005, 'The Winner's Curse of Human Capital', Small Business Economics 24, 63-78.

Audretsch, D. B., 2000, Entrepreneurship in Germany, in D. L. Sexton and H. Landstrom (eds.), The Blackwell Handbook of Entrepreneurship, Oxford, UK: Blackwell Publishing, $107-127$.

Backes-Gellner, U., G. Demirer and P. Moog, 2000, Hochschulinduzierte Gründungen im Kontext der Gründungsforschung: Grenzen und Lösungsmöglichkeiten einer empirischen Analyse, in D. Bögenhold. (ed.), Kleine und Mittlere Unternehmen im Strukturwandel, Frankfurt am Main: Peter Lang Verlag, 123-140.

Bankhofer, and Hilbert, 1995, 'Eine empirische Untersuchung zum Berufseinstieg von Wirtschafts- und Sozialwissenschaftlern', Zeitschrift für Betriebswirtschaft 65, 1423-1441.

Bates, T., 1990, 'Entrepreneur Human Capital Inputs and Small Business Longevity', Review of Economics and Statistics 72, 551-559.

Bernhardt, D., 2000, 'Credit Rationing?', American Economic Review 90, 235-239.

Berning, E., 1982, 'Gründe für überlange Studienzeiten', Bayerische Hochschulforschung, Materialie 32, Munich.

Besanko, D. and A. V. Thakor, 1987, 'Collateral and Rationing: Sorting Equilibria in Monopolistic and Competitive Credit Markets', International Economic Review 28, 671-689.

Bester, H, 1985, 'Screening vs. Rationing Credit Markets', The American Economic Review 75, 850-855.

Binks, M. R. and C. T. Ennew, 1996, 'Growing Firms and the Credit Constraint', Small Business Economics 8, 17-25.

Birch, D. L., 1979, The Job Generation Process, Cambridge: M.I.T. Program on Neighbourhood and Regional Change.

Black, J., D. De Meza and D. Jeffreys, 1992, House Prices, the Supply of Collateral and the Enterprise Economy, Discussion Paper in Economics Nr. 92/08, University of Exeter.

Blumberg, B. F. and W. A. Letterie, 2004, Which Business Starters Experience Limited Access to Bank Funds? in A.-K. Achleitner, H. Klandt and L. T. Koch (eds.), Heidelberg: Jahrbuch für Entrepreneurship, 177-192.

Boot, A. W. A. and A. V. Thakor, 1994, 'Moral Hazard and Secured Lending in an Infinitely repeated Credit Market Game', International Economic Review 35, 899-920.

Bosma, N., M. van Praag, R. Thurik and G. de Wit, 2004, 'The Value of Human and Social Capital Investments for the Business Performance of Startups', Small Business Economics 23, 227-236.

Brüderl, J., P. Preisendörfer and R. Ziegler, 1996, Der Erfolg neugegründeter Unternehmen - Eine empirische Studie zu den 
Chancen und Risiken von Unternehmensgründungen, Berlin: Duncker \& Humblot.

Brüderl, J., P. Preisendörfer and R. Ziegler, 1998, 'Fast Growing Businesses - Empirical Evidence from a German Study', International Journal of Sociology 30, 45-70.

Chamley, C., 1983, 'Entrepreneurs Abilities and Liabilities in a Model af Self-Selection', Bell Journal of Economics 14, $70-80$.

Cooper, A. C., F. J. Gimeno-Gascon and C. Y. Woo, 1994, 'Initial Human and Financial Capital as Predictors of New Venture Performance', Journal of Business Venturing 9, 371395.

De Meza, D and D. C. Webb, 1987, 'Too much Investment: A Problem of Asymmetric Information', Quarterly Journal of Economics 36, 281-292.

Egeln, J., G. Licht and F. Steil, 1997, 'Firm Foundations and the Role of Financial Constraints', Small Business Economics 9, 137-150.

Egger, U. P. and P. Gronemeier, 1999, Existenzgründung, Wiesbaden: Gabler Verlag.

Evans, D. S. and B. Jovanovic, 1989, 'An Estimated Model of Entrepreneurship Choice under Liquidity Constrains', Journal of Political Economy 97, 808-828.

Ghatak, M. and T. W. Guinnane, 1999, 'The Economics of Lending with Joint Liability: Theory and Practice', Journal of Development Economics 60, 195-228.

Harris, M. and A. Raviv, 1991, 'The Theory of Capital Structure', Journal of Finance 46, 297-355.

Holtz-Eakin, D., D. Joulfaian and H. S. Rosen, 1994, 'Sticking it out: Entrepreneurial Survival and Liquidity Constraints', Journal of Political Economy 102(1), 334-347.

Huyghebaert, N. and L. M. Van de Gucht, 2002, The Determinants of Financial Structure: New Insights from Business Start-ups, Belgium: Working Paper. Katholieke Universiteit Leuven.

Informationsdienst des Instituts der deutschen Wirtschaft (IWD), 2002, 'Studienabbrecher- Die Puste ausgegangen', IWD 49, 2.

Lazear, E. P., 1977, 'Academic Achievement and Job Performance: Note', American Economic Review 67, 252-254.

Lind, T. and H. Ohlsson, 1996, 'Self-Employement and Windfall gains: Evidence from Swedish Lottery', The Economic Journal 106, 1515-1526.

Lofstrom, M., 2000, 'A Comparison of the Human Capital and Signaling Models: The Case of the Self-Employed and the Increase in the Schooling Premium in the 1980's', Discussion Paper 160, Institute for the Study of Labor, Bonn.

Lück, W. and A. Böhmer, 1994, 'Entrepreneurship als wissenschaftliche Disziplin in den USA', Zeitschrift für betriebswirtschaftliche Forschung 46, 403-421.

McDermott, C. M. and G. C. O'Connor, 2002, 'Managing Radical Innovation: An Overview of Emergent Strategy
Issues', Journal of Product Innovation Management 19, 424-438.

Minks, K. H., 1992, 'Absolventenreport Wirtschaftswissenschaften. Ergebnisse einer Untersuchung zum Berufsübergang von Absolventen wirtschaftswissenschaftlicher Studiengänge des Prüfungsjahres 1988/89', German Federal Ministry of Education and Research.

Moog, P. and U. Backes-Gellner, 2003, When do start-ups grow? Academy of Management AoM Conference, August 5th 2003, Seattle.

Moog, P., 2004, 'Humankapital des Gründers und Erfolg der Unternehmensgründung' Gabler Edition Wissenschaft, Reihe Entrepreneurship Bd. 4. Wiesbaden.

Nooteboom, B., 1993, 'Firm Size Effects on Transaction Costs', Small Business Economics 5, 283-295.

Parker, S. C., 2004, The Economics of Self-Employment and Entrepreneurship, Cambridge: University Press.

Parker, S. C. and M. van Praag, 2005, 'Schooling, Capital Constraints and Entrepreneurial Performance', Tinbergen Institute Discussion Paper No. TI 2004-106/3.

Ravid, S. and M. Spiegel, 1997, 'Optimal Financing Contracts for a Start-up with Unlimited Operating Discretion', Journal of Financial and Quantitative Analysis 32, 269-286.

Schaeper, H. and K. H. Minks, 1997, Studiendauer - eine empirische Analyse ihrer Determinanten und Auswirkungen auf den Berufseintritt, Hannover: HIS Kurzinformation.

Spence, M., 1973, 'Job Market Signaling', Quarterly Journal of Economics 87, 355-374.

Stiglitz, J. and A. Weiss, 1981, 'Credit Rationing in Markets with Imperfect Information', American Economic Review 71, 393-410.

Stiglitz, J. and A. Weiss, 1983, 'Incentive Effects of Terminations: Applications to the Credit and Labour Markets', American Economic Review 73, 912-927.

Storey, D. J. and B. Tether, 1996, Review of the Empirical Knowledge and an Assessment of Statistical Data on the Economic Importance of new Technology Based Firms, Country Report for Great Britain, Coventry.

Van Praag, M., 2003, Initial Capital Constrains Hinder Entrepreneurial Performance: An Empirical Analysis. CESifo Working Paper Series No. 887.

Webb, D. C., 1991, 'Long-Term Financial Contracts can Mitigate the Adverse Selection Problem in Project Financing, International Economic Review 32, 305-320.

Wissenschaftsrat, 2002, Empfehlungen zur Stärkung wirtschaftswissenschaftlicher Forschung an Hochschulen. Saarbrücken, 15. November 2002, Drs. 5455-02.

Wolpin, K. I., 1977, 'Education and Screening', The American Economic Review 67, 949-958. 